\title{
Økonomisk diplomati får stigende betydning
}

\section{Af Svend Roed Nielsen}

I udenrigsministerierne verden over - og i andre ministerier - taler man nu mere og mere om behovet for økonomisk diplomati. Senest har den danske regering i maj i år fremlagt en strategi for eksportfremme og økonomisk diplomati. Man hvad er økonomisk diplomati, og hvorfor får det stigende betydning?

Traditionelt har det kommercielle diplomati ikke været så anset og prestigiøst som de fleste andre former for diplomati. Det er ikke mange år siden, at økonomisk diplomati blev anset for at være en lidt købmandsagtig aktivitet, der ikke lå på niveau med de 'rigtige' diplomaters arbejde for at sikre verdensfreden, udvikle EU, kæmpe for menneskerettigheder og miljø samt sikre udvikling og fattigdomsbekæmpelse. Man var ikke med blandt de fine diplomater, hvis man havde den opfattelse, at eksportfremme var sagen, og man måtte derfor leve med en plads i bunden af det di- plomatiske hierarki. Men sådan er det ikke længere. I dag står diplomaterne i kø for at beskæftige sig med økonomisk diplomati, og en af de vigtigste årsager er den økonomiske krise fra 2008.

Her blev den globale økonomiske situation pludselig storpolitik, og det internationale samarbejde om at begrænse krisen blev afgørende for at sikre beskæftigelse, velfærd og regeringers overlevelse. I kølvandet på krisen blev de offentlige bevillinger sat under pres, og skulle udenrigsministerierne undgå for dybe beskæringer i budgetterne, måtte man dokumentere mere end nogensinde, at man var pengene værd her og nu ikke mindst ved at bidrage til eksport, investeringer og beskæftigelse.

Dette 'wake up call' for udenrigsministerierne var imidlertid også led i en længere globaliseringsproces, hvor stadig større dele af et samfund inddrages i de globale værdikæder og samarbejde. Man må derfor ikke bare i udenrigsministerierne, men også i andre ministerier samt styrelser og organisationer have mere kenskab til, hvad

Svend Roed Nielsen har siden 2009 været ambassadør i Brasilien. Fra 1. september har han været tilbage i Udenrigsministeriet i København i Center for Eksportrådet. Her har han bl.a. ansvaret for at udvikle samarbejdet på især det økonomiske diplomatis område mellem Eksportrådet og De Danske Regioner. 


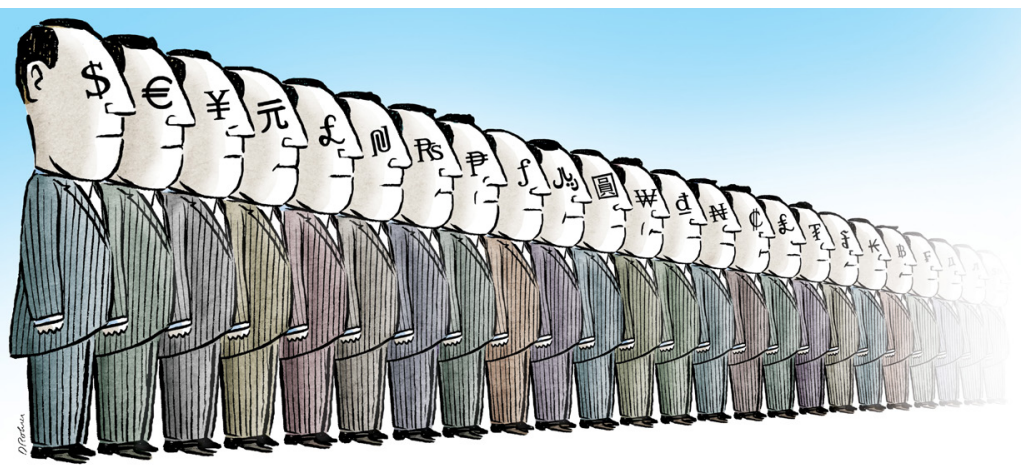

der sker internationalt, og hvordan man agerer i et internationalt miljø. Denne globalisering betyder, at stadig flere aktører inddrages i økonomisk diplomati.

I takt med globaliseringen bliver vi desuden kommercielt mere aktive på ikkevestlige landes markeder. Her er forholdene ofte meget anderledes end i Europa og Nordamerika med en stor grå zone mellem det kommercielle marked og myndighederne, hvilket øger behovet for, at danske virksomheder sammen med Udenrigstjenesten går i dialog med landets myndigheder for at sikre vore virksomheder de bedst mulige økonomiske vilkår.

I den danske regerings strategi for eksportfremme og økonomisk diplomati defineres sidstnævnte på følgende måde: "Økonomisk diplomati er en tværgående aktivitet, der involverer hele Udenrigstjenesten, andre ministerier og myndigheder samt private aktører. Formålet er at kombinere værktøjer for at forfølge udenrigspolitiske og økonomiske mål, hvor det økonomiske diplomati leverer internationale bidrag til dansk vækst og beskæftigelse".

Økonomisk diplomati er således mere omfattende end eksportfremme og handelspolitik. Det omfatter også arbejdet i internationale organisationer som Verdensbanken, EU og andre, som varetager økonomiske opgaver. Økonomisk diplomati omfatter tillige vigtige dele af det internationale samarbej- de om videnskab, innovation og uddannelse samt væsentlige dele af udviklingssamarbejdet, offentlighedsdiplomati/nationbranding og turistfremme.

Den øgede vægt på økonomisk diplomati gør naturligvis ikke andre former for diplomati mindre vigtige. Der er stadig behov for diplomatisk indsats i arbejdet for fred og sikkerhed, kampen for menneskerettigheder, konsulære opgaver samt opretholdelse af et internationalt retssamfund.

\section{Samtænkning}

Økonomisk diplomati kan imidlertid i højere grad integreres i disse andre former for diplomati. Der kan således være gensidige gevinster ved at samtænke udviklingsbistand med kommercielle interesser. Anvendelse af danske virksomheders styrkepositioner i udviklingsaktiviteter kan bidrage til løsning af centrale udfordringer i udviklingslande og samtidig skabe vækst og beskæftigelse i Danmark.

Det danske Udenrigsministerium havde en gunstig udgangsposition for at sikre sig en central placering i dansk økonomisk diplomati. To ting var særligt vigtige:

I kraft af den måde, vi har indrettet vores EU-samarbejde på, har Udenrigsministeriet en model, hvor vi både kan decentralisere ud til de ministerier og styrelser, der har ekspertisen, og samtidig sikre koordination af den samlede danske politik. 
Vigtige dele af EU-samarbejdet er økonomisk diplomati - med det indre marked og EU's handelspolitik som oplagte eksempler. I andre lande opereres der med en langt mere decentral struktur og dermed et svagere placeret udenrigsministerium.

For det andet havde Udenrigsministeriet med Danmarks Eksportråd allerede ansvaret for eksportfremme, og der er en regeringsbeslutning om, at vi bør opretholde en enstrenget struktur på dette område. Hertil kommer, at også tiltrækning af investeringer, innovation og handelspolitik er en integreret del af Udenrigsministeriet, hvilket også gælder for bistandspolitikken. I andre lande ligger disse aktiviteter ofte uden for udenrigsministeriets ressort, hvilket vanskeliggør koordineringen.

Det betyder ikke, at der mangler udfordringer med hensyn til at sikre et stærkt og koordineret dansk økonomisk diplomati. For det første skal Udenrigsministeriet løbende dokumentere, at arbejdet udføres optimalt i kraft af, at disse aktiviteter er integreret i ministeriet. Hver ny finanslov og hver ny regeringsdannelse giver anledning til at sætte spørgsmålstegn ved denne tingenes tilstand.

\section{Mange aktører}

For det andet rækker økonomisk diplomati nu videre ud i samfundet og ind på områder, hvor Udenrigsministeriet ikke er den ansvarlige myndighed.

Skal danske virksomheder operere optimalt på de nye markeder, kræver det dialog med myndighederne for at fjerne barrierer. Det kan fx dreje sig om myndigheder, der skal give licenser til import af medicin og fødevarer, og hvor Sundhedsstyrelsen og Fødevarestyrelsen i Danmark er centrale spillere.

De overordnede danske bilaterale politiske relationer til de nye vækstlande er i betydelig grad afhængig af, at vi er i stand til at levere det, som disse lande har brug for i deres økonomiske udvikling. Det drejer sig bl.a. om uddannelse, sundhed, vel- færd, miljø, erhvervslovgivning og forskning. Her bliver økonomisk diplomati det centrale redskab for at styrke de overordnede danske bilaterale diplomatiske relationer til disse lande. De, der kan levere disse løsninger, er typisk ikke Udenrigsministeriet, men en lang række andre ministerier og styrelser, og som derfor bliver centrale aktører i dansk udenrigspolitik.

Udenrigsministeriet kan kun udføre økonomisk diplomati på disse områder i tæt samarbejde med andre. Det kræver evne til at samarbejde og koordinere, og lykkes det ikke for Udenrigsministeriet i det lange løb, vil det blive mere og mere overflødigt.

Mere økonomisk diplomati vil øge behovet for mere ekspertise ude på ambassaderne - ekspertise som Udenrigsministeriet ikke kan eller skal levere. Flere eksperter fra andre ministerier vil fremme muligheden for på stedet at levere det økonomiske diplomati, der udmeldes fra København. Samtidig bør Udenrigsministeriet også personalemæssigt blive bedre integreret $\mathrm{i}$ de øvrige ministerier på Slotsholmen, der er centrale for økonomisk diplomati.

Dernæst er der udfordringen med at få et effektivt samarbejde med de egentlige brugere af økonomisk diplomati, nemlig de internationalt arbejdende danske virksomheder. I Danmark har vi en stærk tradition for, at det offentlige søger dialogen med virksomhederne via deres organisationer som DI og Landbrug \& Fødevarer. Dette skal forsætte, men samarbejdet kan udbygges, dels med brancheklubber af virksomheder ude på de større markeder, og dels øget inddragelse af regionernes erhvervsarbejde.

\section{Ikke lobbyvirksomhed}

Er der grænser for, hvad der kan gøres for at fremme danske kommercielle interesser under økonomisk diplomati? Svaret er ja.

Danske ambassader er ikke lobbyvirksomheder, der kan betales for at arbejde for hvad som helst. Man bør ikke ved økono- 
misk diplomati kunne fremme kommercielle formål for danske virksomheder på bekostning af andre klare mål, som den danske regering ønsker at give prioritet, så som respekt for menneskerettigheder, bedre miljø og øget fattigdomsbekæmpelse. Vi bør heller ikke støtte virksomheder i aktiviteter, hvis formål er i modstrid med lovgivning eller administrativ praksis, som et andet lands myndigheder klart ønsker overholdt.

I virkelighedens verden er det ikke så let at trække en rød linje. Prioriteter er sjældent absolutte, men typisk skal der foretages en afvejning mellem flere hensyn. Opholdslandets lovgivning eller administrative praksis kan nok være klar, men ikke hensigtsmæssig for at nå de mål, som regeringen selv ønsker. Så er det vel legi- timt, at vi udefra argumenterer imod denne lovgivning og søger den ændret. Det er en balancegang. Vi skal respektere egne love, normer og prioriteter, og samtidig vil vi med økonomisk diplomati ofte blande os $i$ et andet lands indre anliggender.

Vil behovet for økonomisk diplomati vokse og vil det ske inden for eller uden for Udenrigsministeriet? Alt tyder på, at det globale samarbejde på alle niveauer kun vil blive forstærket fremover. Det samme gælder økonomisk diplomati, og hovedudfordringen vil være samordningen mellem de mange forskellige aktører. Udenrigsministeriet skal her ikke være overdommer, men skal være centralt placeret og kunne tage teten for at sikre et koordineret og slagkraftigt dansk økonomisk diplomati. 